\title{
EFFECT OF WEED CONTROL TREATMENTS ON SOME BREAD WHEAT CULTIVARS PRODUCTIVITY AND ITS ASSOCIATED WEEDS
}

\author{
(Received:10.6.2021)
}

\author{
By \\ May H. M. Elattar and A.T. H. Moustafa* \\ Weed Research Central Laboratory and *Wheat Research Section, \\ Field Crops Research Institute, Agriculture Research Center, Giza, Egypt.
}

\begin{abstract}
Two field experiments were carried out during the two successive growing seasons of 2017-18 and 2018-19 at Mallawy Agricultural Research Station, Agric. Res. Center, Egypt, to study the effect of weed control treatments on yield and yield components of some Egyptian bread wheat cultivars and its associated weeds. The experiments were laid out in a randomized complete blocks design (RCBD) with split-plot arrangement with four replications. The main plots were assigned to five bread wheat cultivars Misr-1, Misr-2, Shandaweel-1, Sids-14 and Giza-171, and seven weed control treatments (Pallas 4.5 \% OD, Atlantis 1.2 \% OD, Broadway-star 8.5 \% WG, Liprator fort $36 \%$ SC and Onostar $75 \%$ WF ,followed by Traxsos 5\% EC), as well as hand weeding twice and unweeded check were allocated in sub-plots. The results showed that the cultivars were significantly affected the dry weight of total annual weeds. The wheat cultivars were significantly different in yield and its attributes such as number of spike/ $\mathrm{m}^{2}$, number of kernels/spike, 1000 kernels weight $(\mathrm{g})$, harvest index (HI) \% and grain yield (ardab/fad). The greatest value of grain yield was recorded by cv. Shandaweel-1. The highest competitive ability of cultivars (CAC\%) and the least dry weight of total annual weeds was achieved by cv. Misr-2 and Giza-171. Also, the herbicides (Onostar followed Traxsos, Atlantis, Broadway star and Pallas) as well as twice hand weeding showed the highest reduction in dry weight (g) of weeds and the highest weed control efficiency (WCE\%). While, the least effective herbicide was Liprator fort. The treatments of Pallas, (Onostar followed by Traxsos), Atlantis and broadway star as well as hand weeding achieved the highest increment in wheat yield and its components. The interaction effect between wheat cultivars (Shandaweel-1, Misr-2 and Misr-1) and the herbicides Pallas, Onostar followed by Traxsos showed the least dry weight of total annual weeds and gave the highest wheat grain yield followed Atlantis and Broadway star. Planting wheat cultivar Shandaweel-1 and controlling weeds by hand weeding twice at 30 and 45 days, or by using herbicides Onostar followed by Traxsos produced the highest wheat grain yield followed by Atlantis, Pallas or Broadway star.
\end{abstract}

Key words: Bread wheat, cultivars, weed control, herbicides, hand weeding.

\section{INTRODUCTION}

Bread wheat (Triticum aestivum L.) is an important stable food crop and serves as backbone of food security in Egypt. The wheat is cultivated on an area of 1.33 million hectares (3.17 million faddan) with grain yield average of 6.4 ton ha $^{-1}\left(17.85\right.$ ardabab faddan $\left.{ }^{-1}\right)$ during 2019/2020 season In Egypt. (Economic Affairs sector, 2020).

Wheat productivity depends on several factors like crop establishment techniques, irrigation, weed competition, fertilizers management, cultivars and other cultural practices (Meena et al., 2017). The response of wheat plants to herbicides varied among cultivars (Brar et al., 1997). Using high competitive cultivars can be effective for weed growth suppression (Mennan and Zandstra 2005). Weeds are the major deterrent to the development of sustainable crop production and is the key factor in decreaing yield (LopezGranados, 2011). Weed problem is one of the major barriers responsible for low productivity of wheat because, weed competes with the crop for essential growth factors like moisture, nutrients, space, and light etc. Moreover, they increase production cost, harbors insects and plant diseases, decrease quality of farm produce 
and reduce values of the land (Tesfaye et al., 2014). The weed infestation is the basic and major component of low yield in crop production system and causes enormous loss of about 58.6\% (Dawit et al. (2014) and 37 to 57.1 $\%$ due to their interference (Verma et al., 2015), intensity of infestation, crop species and cultivars (Atnafu ,2019).

Wheat usually suffers stress created by mixflora of weeds through competition along with interference caused by secreting toxic substances to the rhizosphere of the crop plants (Meena et al., 2017). Presence of weeds especially at early growth stages causes more reduction in growth and yield of wheat. Yield losses are most severe when resources are limited and weeds with crops emerge simultaneously (Hussain et al., 2015).

Hucl (1998) found that the less competitive genotypes suffered a 7-9\% greater yield loss than that of the more competitive genotypes. The response of wheat genotypes to herbicides varied among cultivars (Abusteit et al., 1991). Abouziena et al. (2008) found that under the weed competition condition; Sids 9 cultivar produced the highest grain yield, while under unweeding treatment; Sids 7 cultivar gave the maximum yield.

Mason et al. (2008) reported that tallness, early heading and maturity were related to increase grain yield at the highest weed infestation. They added that greater spikes $/ \mathrm{m}^{2}$, tallness and early heading were associated with reduced weed biomass, depending on weed infestation.

Herbicides appears to be economical method of weed control (Dalley et al.,2006) and Bari et al., (2020). Herbicides are used to increase crop yield (Jabran et al.,2008), decrease dry weight of weed (Ahmad et al., 1993) and increase nutrient uptake by wheat (Bharat $e t$ al., 2012).

Vasudev et al. (2017) and Zand et al., (2010) concluded that the pre-mix application either of metsulfuron+sulfosulfuron or mesosulfuron+iodosulfuron as post-emergence should be used for the control of complex weed flora in wheat crop. Soltani and Saeedipour (2015) found that the application of Chevalier herbicide (Mesosulfuron-methyl plus Iodosulfuron-methyl) decreased weed dry matter by $86.2 \%$. The excellent control of complex weed flora in wheat was observed with the mix application of clodinafop+metsulfuron and mesosulfuron-methyl+idosulfuron-methyl sodium (Singh et al.,2015). Deboer et al., (2006) reported that Pyroxsulam is a systemic herbicide applied in cereals at early postemergence, its selectiveness and effectiveness to winter and spring wheat cultivars when combined with the safener cloquintocet-mexyl in commercial herbicide product formulations.

Weed problems on wheat crops is increasing and there are many options for weed control that can reduce infestation and enhance wheat quality and productivity. Hence the objectives of this study was to determine the best cultivars and weed control treatments to achieve the highest grain yield and its component of Egyptian bread wheat.

\section{MATERIALS AND METHODS}

Two field experiments were carried out during two successive growing seasons of 2017/2018 and 2018/2019 at Mallawy Agricultural research station, Agric. Res. Center, to study the effect of weed control treatments on yield and its yield components of some Egyptian bread wheat cultivars and its associated weeds.

The experiment included 35 treatments (5 cultivars and 7 weed treatments). The preceding summer crop was maize (Zea mays L.) in both seasons. The soil types of this study were silty clay loam texture with 8.99 and $8.14 \%$ sand, 53.32 and $54.35 \%$ silt and 37.69 and $37.51 \%$ clay, $\mathrm{pH}$ were 8.01 and 8.14 with organic matter of 1.14 and $1.18 \%$ in 2017/2018 and 2018/2019 seasons, respectively. A randomized complete blocks design (RCBD) using split-plot arrangement with four replications was used in this study and the treatments were arranged as follows:

The main plots included five wheat cultivars (names, pedigree and selection history of the studied cultivars are listed in Table (1) (Sadek, Eman et al.,2013) ; (Hamada et al.,2015). (Hamada et al. ,2017) and (Abdel-Majeed et al. ,2017)

1. Pyroxulam known commercially as Pallas $4.5 \% \mathrm{OD}$ at rate of $160 \mathrm{~cm}^{3} / \mathrm{fad}$ applied at 35 leaf stage.

2. Pyroxulam + florasulam a ready formulated herbicide known commercially as Broadway star $8.5 \% \mathrm{WG}$ at rate of $120 \mathrm{~g} / \mathrm{fad}$ applied at 3-5 leaf stage.

3. Mesosulfuron-methyl $3 \%+$ iodosulfuronmethyl sodium $0.6 \%$ a ready formulated herbicide known commercially as Atlantis $1.2 \% \mathrm{OD}$ at rate of $400 \mathrm{~cm}^{3} / \mathrm{fad}$ applied at 35 leaf stage. 
Table (1): Cultivars, pedigree and selection history of the studied Egyptian bread wheat cultivars.

\begin{tabular}{|c|c|l|}
\hline No. & Cultivar & \multicolumn{1}{c|}{ Pedigree and selection history } \\
\hline $\mathbf{1}$ & Misr-1 & $\begin{array}{l}\text { OASIS/SKAUZ//4*BCN/3/2*PASTOR. CMSS00Y01881T -050M- } \\
\text { 030Y-030M-030WGY-33M- } \\
\text { 0Y-0EGY. }\end{array}$ \\
\hline $\mathbf{2}$ & Misr-2 & $\begin{array}{l}\text { SKAUZ/BAV92. } \\
\text { CMSS96M03611S-1M-010SY-010M-010SY-8M-0Y- EGY. }\end{array}$ \\
\hline $\mathbf{3}$ & Shandaweel-1 & $\begin{array}{l}\text { SITE//MO/4/NAC/TH.AC//3*PVN/3/MIRLO/BUC. } \\
\text { CMSS93B00567S-72Y-010M-010Y-010M- 0HTY-0SH. }\end{array}$ \\
\hline $\mathbf{4}$ & Giza-171 & $\begin{array}{l}\text { Sakha 93 / Gemmiza 9 S.6-1GZ-4GZ-1GZ-2GZ-0S. Gz2003-101- } \\
\text { 1GZ-4GZ-1GZ-2GZ-0Gz. }\end{array}$ \\
\hline $\mathbf{5}$ & Sids14 & $\begin{array}{l}\text { Bow"s"/Vee"s"//Bow"s"/TSI/3/Bani Sewef 1. } \\
\text { SD293-1SD-2SD- 4SD - OSD. }\end{array}$ \\
\hline
\end{tabular}

A. The sub-plots (Weed control treatments):

4. Diflufenican + flufenacet + flurtamone $a$ ready formulated herbicide known commercially as Liprator fort $36 \% \mathrm{SC}$ at rate of $400 \mathrm{~cm}^{3} /$ fad applied at 3-5 leaf stage.

5. Tribenuron-methyl known commercially as Onostar $75 \% \mathrm{WF}$ at rate of $8 \mathrm{~g} / \mathrm{fad}$ applied at 2-4 leaf stage. followed by clodinafoppropargyl + pinoxadin a ready formulated herbicide known commercially as Traxos 5\% EC at rate of $500 \mathrm{~cm}^{3} / \mathrm{fad}$ applied at $30-45$ days after planting.

6. Hand weeding twice at 30-45 days after planting.

7. Unweeded (check).

The experiment included 140 wheat plots (experimental unit), the plot area was $10.5 \mathrm{~m}^{2}$ (3.5 m length $\times 3 \mathrm{~m}$ width). Seeding rate was 60 $\mathrm{kg} / \mathrm{fad}$ The herbicides were applied as per treatments on the assigned plots using $\mathrm{Cp} 3$ knapsack sprayers with 200 litter of water/fad Wheat (Triticum aestivum L.) was sown on $18^{\text {th }}$ and $21^{\text {st }}$ of November in the first and second season, respectively; all wheat growing agricultural practices were done as recommended. The average air temperature during the growth seasons was obtained from Mallawy wheather station (Fig. 1). The harvest time was $1^{\text {st }}$ and $5^{\text {th }}$ of May in the first and second season, respectively.

\subsection{Data recorded}

The following data were recorded

\subsection{Weed survey}

The weed were hand pulled from random one square meter from each plot 75 days after sowing (DAS), then identified according to Täckholm (1974) into species and classified into annual grassy, broad-leaved and total weeds. Weed samples were air-dried and then kept in an electric oven at $65-70^{\circ} \mathrm{C}$ till constant weight achieved.
Weed control efficiency (WCE) has been calculated according to Meena et al., (2017) with the following formula:

$$
\boldsymbol{W C E} \%=
$$

$$
C A C \%=\frac{\text { yield of unweeded plots }}{\text { yield of hand weeded plot }} \times 100
$$

Competitive ability of cultivars (CAC\%) has been calculated according to Abouziena et al., (2008) with the following formula:

\subsubsection{Wheat yield and its components}

Number of spikes $/ \mathrm{m}^{2}$ were taken after maturity. At harvest time, grain yield (ardab/fad), harvest index (HI) \%, number of kernels/spike and 1000-kernels weight (g) were recorded.

\subsection{Statistical analysis}

All data were statistically analyzed according to technique of analysis of variance (ANOVA) as mentioned by Gomez and Gomez (1984) using "MSTAT-C" (1989) computer software package and least significant differences (L.S.D.) was calculated to compare between treatments means.

\section{RESULTS AND DISCUSSION}

\subsection{Weed population}

The main weeds in the experimental field were common wild oat (Avena spp. L.), canary grass (Phalaris minor L.) as a grassy weed and wild mustrad (Sinapis arvensis L.), lampsquarters (Chenopodium album L.), annual sowthistle (Sonchus oleraceus L.), sweet clover (Melilotus indica L.) and toothed medik (Midicago polymorpha) as broad-leaved weeds. Generally, the greater reduction of yield crop occurs linearly with the increment in the density 


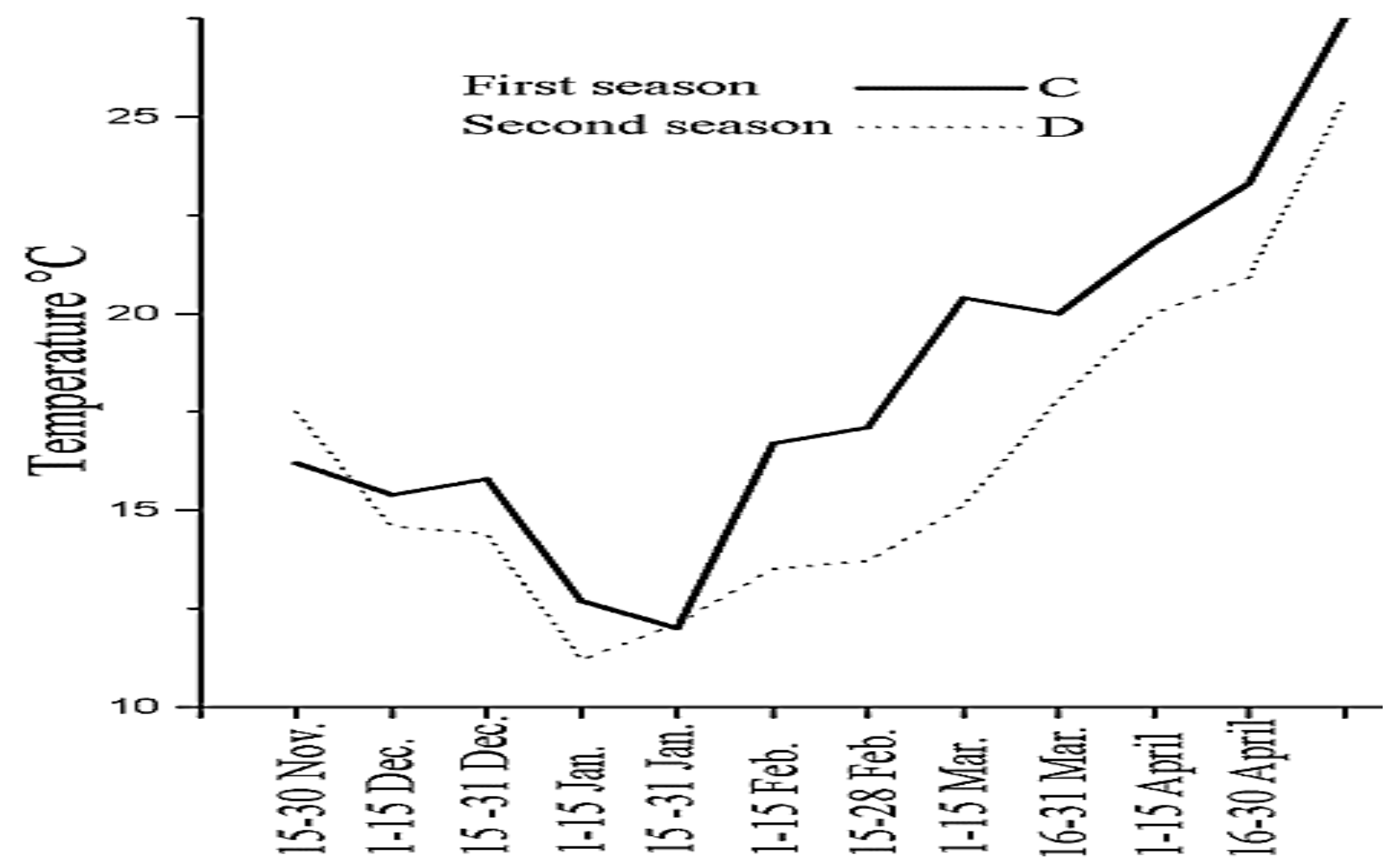

Fig. (1): Average temperature in 2017/2018 and 2018/2019 season.

of weeds. whereas, weed grow quicker than crop plants (Atnafu ,2019).

\subsection{Analysis of variance}

\subsubsection{Weed traits}

The analysis of variance in Table (2) indicated that the effect of wheat cultivars (A) on dry weight of grassy, broad-leaved and total annual weeds was significant in both seasons, except total annual weeds in the second season. Weed control treatments (B) and the interaction between wheat cultivars and weed control treatments $(\mathrm{AB})$ significantly affected the dry weight of grassy, broad-leaved and total annual weeds in both seasons.

\subsubsection{Wheat traits}

The analysis of variance in Table (3) showed that the effects of wheat cultivars (A) and weed control treatments (B) on no. of spikes $/ \mathrm{m}^{2}$, no. of kernels/spike, 1000 kernels weight, grain yield (ardab/fad) and harvest index (\%) were significant in both seasons. The interaction between cultivars and weed treatments $(A B)$ showed significant effects on all studied wheat traits in both seasons-exceptno. of kernels/spike, 1000 kernels weight and harvest index in the second season

\subsection{Effect of wheat cultivars on}

\subsubsection{Weed dry weight $\left(\mathrm{g} / \mathrm{m}^{2}\right)$}

Data presented in Table (4) revealed significant differences between wheat cultivars regardabing to their effects on dry weight of grassy, broad-leaved and total annual weeds $\left(\mathrm{g} / \mathrm{m}^{2}\right)$ in both seasons-except- total annual wees in the second season. Among tested cultivars, Misr-2 showed the lowest dry weight of total annual weed in both seasons (584.18 and 509.71 $\mathrm{g} / \mathrm{m}^{2}$ ). This result may be due to the competitive ability of Misr-2 on weeds. Many authors reported that the competitive ability of wheat plants varied between cultivars Abusteit et al., (1991) and Brar et al. (1997). These results are in harmony with that reported by Bussan et al. (1997) and Abouziena et al. (2008).

\subsubsection{Wheat yield and its components}

Table (5) shows that wheat cultivars were varied and showed significant differences for all studied characters (no. of spikes $/ \mathrm{m}^{2}$, no. of kernels/spike, 1000-kernels weight (g), yield (ardab/fad) and harvest index (\%) in both seasons, except- 1000 kernels weight in the second season. Wheat cv. Shandaweel-1 gave the highest values for grain yield (19.28 and $21.99 \mathrm{ardab} / \mathrm{fad})$ in the first and second seasons, respectively, and wheat cv. Giza-171 was the 
Table (2): Analysis of variance for weeds dry weight $\left(\mathrm{g} / \mathrm{m}^{2}\right)$ as affected by wheat cultivars, weed control treatments as well as their interaction in 2017/2018 and 2018/2019 seasons.

\begin{tabular}{|l|c|c|c|c|}
\hline SOV & d.f. & $\begin{array}{c}\text { MS of grassy } \\
\text { weeds }\end{array}$ & $\begin{array}{c}\text { MS of broad-leaved } \\
\text { weeds }\end{array}$ & $\begin{array}{c}\text { MS of total annual } \\
\text { weeds }\end{array}$ \\
\hline \multicolumn{7}{|c|}{$\mathbf{2 0 1 7 / 2 0 1 8}$} \\
\hline Replication & 3 & 473.69 & 917.86 & 905.83 \\
\hline Factor A & 4 & $25108.81^{*}$ & $21767.91^{*}$ & $57310.13^{*}$ \\
\hline Error & 12 & 7427.91 & 5452.54 & 11154.80 \\
\hline Factor B & 6 & $7623827.93^{* *}$ & $4201178.86^{* *}$ & $931028.01^{* *}$ \\
\hline AB & 24 & $25556.14^{* *}$ & $12307.66^{* *}$ & $35031.26^{* *}$ \\
\hline Error & 90 & 5871.92 & 4261.99 & 6632.27 \\
\hline \multicolumn{5}{|c|}{$\mathbf{2 0 1 8 / 2 0 1 9}$} \\
\hline Replication & 3 & 1966.79 & 317.81 & 3373.91 \\
\hline Factor A & 4 & $20610.40^{* *}$ & $8697.48^{*}$ & 6411.59 \\
\hline Error & 12 & 3284.71 & 1816.14 & $18523914.56^{* *}$ \\
\hline Factor B & 6 & $4874860.25^{* *}$ & $5030788.94^{* *}$ & $11203.98^{* *}$ \\
\hline AB & 24 & $9859.61^{* *}$ & $5884.79^{* *}$ & 4216.34 \\
\hline Error & 90 & 2373.83 & 2096.16 & \\
\hline
\end{tabular}

$(A)=$ cultivars, $(B)=$ weeds control treatment,$(A B)=$ interaction between cultivars and weed control treatments.

Table (3): analysis of variance for wheat yield and its components as affected by wheat cultivars, weed control treatments as well as their interaction in 2017/2018 and 2018/2019 seasons.

\begin{tabular}{|c|c|c|c|c|c|c|}
\hline SOV & d.f. & $\begin{array}{l}\text { MS of No. } \\
\text { Spikes/m } \mathbf{m}^{2}\end{array}$ & $\begin{array}{c}\text { MS of No. } \\
\text { kernels } \\
\text { /spike }\end{array}$ & $\begin{array}{c}\text { MS of } 1000 \\
\text { kernels weight }\end{array}$ & $\begin{array}{c}\text { MS of } \\
\text { Grain yield }\end{array}$ & $\begin{array}{c}\text { MS of } \\
\text { Harvest } \\
\text { index }\end{array}$ \\
\hline \multicolumn{7}{|c|}{$2017 / 2018$} \\
\hline Replication & 3 & 259.09 & 29.81 & 1.86 & 0.18 & 5.12 \\
\hline Factor A & 4 & $4725.55^{*}$ & $1094.06^{* *}$ & $21.59 * *$ & $13.29 * *$ & $120.23 * *$ \\
\hline Error & 12 & 950.36 & 20.14 & 2.35 & 0.85 & 3.48 \\
\hline Factor B & 6 & $124099.43 * *$ & $752.33 * *$ & $82.05 * *$ & $350.18 * *$ & $461.91 * *$ \\
\hline $\mathrm{AB}$ & 24 & $632.64^{*}$ & $29.01 * *$ & $6.47 * *$ & $2.95 * *$ & $26.05 *$ \\
\hline Error & 90 & 363.39 & 25.38 & 2.75 & 1.15 & 15.27 \\
\hline \multicolumn{7}{|c|}{$2018 / 2019$} \\
\hline Replication & 3 & 16.47 & 38.56 & 2.77 & 0.13 & 73.37 \\
\hline Factor A & 4 & $3678.11 * *$ & $473.92 * *$ & 19.98 & $9.62 * *$ & $178.54 *$ \\
\hline Error & 12 & 204.97 & 15.70 & 8.02 & 1.09 & 35.92 \\
\hline Factor B & 6 & $135127.53 * *$ & $888.51 * *$ & $107.94 * *$ & $519.02 * *$ & $390.25 * *$ \\
\hline $\mathrm{AB}$ & 24 & $829.48 * *$ & 36.87 & 7.42 & $2.91 * *$ & 40.79 \\
\hline Error & 90 & 196.23 & 27.44 & 4.80 & 1.26 & 28.46 \\
\hline
\end{tabular}

$(A)=$ cultivars, $(B)=$ weeds control treatments, $(A B)=$ interaction between cultivars and weed control treatments. $*, * *=$ Significant at $\mathbf{p} \geq 0.05, p \geq 0.01$ level of probability respectively.

Table (4): Effect of wheat cultivars on dry weight of grassy, broad-leaved and total annual $\left(\mathrm{g} / \mathrm{m}^{2}\right)$ in 2017/2018 and 2018/2019 seasons.

\begin{tabular}{|l|c|c|c|c|c|c|}
\hline \multirow{2}{*}{ Cultivar } & \multicolumn{2}{|c|}{ Grassy weeds } & \multicolumn{2}{c|}{ Broad-leaved weeds } & \multicolumn{2}{c|}{ Total annual weeds } \\
\cline { 2 - 7 } & $\mathbf{2 0 1 7 / 2 0 1 8}$ & $\mathbf{2 0 1 8 / 2 0 1 9}$ & $\mathbf{2 0 1 7 / 2 0 1 8}$ & $\mathbf{2 0 1 8 / 2 0 1 9}$ & $\mathbf{2 0 1 7 / 2 0 1 8}$ & $\mathbf{2 0 1 8 / 2 0 1 9}$ \\
\hline Misr-1 & 431.25 & 329.89 & 191.79 & 213.21 & 623.04 & 543.1 \\
\hline Misr-2 & 420.21 & 297.64 & 163.93 & 212.07 & 584.14 & 509.71 \\
\hline Shandaweel-1 & 464.57 & 356.07 & 234.25 & 196.11 & 698.82 & 552.18 \\
\hline Sids14 & 396.64 & 287.36 & 224.96 & 244.61 & 621.6 & 531.97 \\
\hline Giza-171 & 466.82 & 318.39 & 204.54 & 219.29 & 671.36 & 537.68 \\
\hline LSD & $\mathbf{5 0 . 1 9} *$ & $\mathbf{3 3 . 3 7} * *$ & $\mathbf{4 3 . 0 0} *$ & $\mathbf{2 4 . 8 2} *$ & $\mathbf{6 1 . 5 0} *$ & NS \\
\hline
\end{tabular}

$*, * *=$ Significant at $\mathbf{p} \geq \mathbf{0 . 0 5}, \mathbf{p} \geq \mathbf{0 . 0 1}$ level of probability respectively and $\mathrm{NS}=$ not-significant. 
Table (5): Effect of wheat cultivars on wheat yield and its components in 2017/2018 and 2018/2019 seasons.

\begin{tabular}{|c|c|c|c|c|c|}
\hline Cultivar & $\begin{array}{c}\text { No. spikes } \\
\text { /.m }\end{array}$ & $\begin{array}{c}\text { No. } \\
\text { kernels/spike }\end{array}$ & $\begin{array}{c}\text { 1000- } \\
\text { kernel } \\
\text { weight (g) }\end{array}$ & $\begin{array}{c}\text { Grain yield } \\
\text { (ardab/fad) }\end{array}$ & $\begin{array}{c}\text { Harvest } \\
\text { index (\%) }\end{array}$ \\
\hline \multicolumn{5}{|c|}{$\mathbf{2 0 1 7 / 2 0 1 8}$} \\
\hline Misr-1 & 341.2 & 52.9 & 44.46 & 17.58 & 39.74 \\
\hline Misr-2 & 332.3 & 59.0 & 44.29 & 17.79 & 40.58 \\
\hline Shandaweel-1 & 361.0 & 70.1 & 44.75 & 19.28 & 44.95 \\
\hline Sids14 & 359.5 & 62.9 & 45.65 & 17.85 & 42.00 \\
\hline Giza-171 & 338.6 & 60.3 & 46.36 & 18.44 & 43.18 \\
\hline LSD 5\% & $\mathbf{1 7 . 9 5}$ & $\mathbf{2 . 6 1}$ & $\mathbf{0 . 8 9}$ & $\mathbf{0 . 5 3 7}$ & $\mathbf{1 . 0 7}$ \\
\hline \multicolumn{7}{|c|}{} & $\mathbf{2 0 1 8 / 2 0 1 9}$ & 20.69 & 42.60 \\
\hline Misr-1 & 371.7 & 58.6 & 51.09 & 20.47 & 42.19 \\
\hline Misr-2 & 365.1 & 67.0 & 51.08 & 21.99 & 46.07 \\
\hline Shandaweel-1 & 384.1 & 64.4 & 51.46 & 21.03 & 45.52 \\
\hline Sids14 & 394.9 & 69.5 & 52.07 & 21.17 & 48.23 \\
\hline Giza-171 & 379.7 & 66.5 & 53.08 & $\mathbf{0 . 6 0 8}$ & $\mathbf{3 . 4 9}$ \\
\hline LSD 5\% & $\mathbf{8 . 3 4}$ & $\mathbf{2 . 3 1}$ & NS & & \\
\hline
\end{tabular}

NS = not-significant

highest cultivar in 1000-kernels weight (46.36g) in the first season. Shandaweel-1 and Sids-14 gave the highest values of no. of spikes $/ \mathrm{m}^{2}$ in both seasons (361 and 359.9 in the first season and 384.1 and 394.9 in the second season, respectively). Regarding to harvest index, Shandaweel 1 gave the highest value of harvest index in the first season (44.95\%), whereas, Giza 171 gave the highest value in the second season $(48.23 \%)$. Also, data illustrated that the first season was lower than the second season for all studied characters. The reduction of yield and its components in the first season may be attributed to the high air temperature in the first season than the second season (Fig.1) or to other factors which may be negatively affect wheat yield and its components. These results are in harmony with those reported by Jagadish (2012). Also, the cultivar differences in grain yield may be attributed to genetical factors (Moustafa and El-Sawi , 2014) and Zeleke et al., 2019) and vegetative growth, tillering and response to environmental conditions (Mennan and Zandstra ,2005).

\subsection{Competitive ability of cultivars (CAC\%)}

Based on the decrease percent (\%) in grain yield/fad, compared to weed-free (hand weeding) condition, the competitive ability of cultivars was different and arranged in descending order in Table (6) as follows: Misr-2 $(58.04 \%)>$ Giza-171 (51.91\%) > Sids-14 $(47.44 \%)>$ Misr-1 (47.35\%) and Shandaweel$1(45.74 \%)$ in first season. While, in the second season, the descending order were arranged as follows: Giza-171 (49.32\%) > Shandaweel-
$1(48.62 \%)>$ Sids-14 (46.83\%)> Misr 2 (44.71)> Misr-1 (40.44\%) in this respect. The differences in competitive ability appear to be related to various attributes including environment, genetic bacground and morphological characteristics of the cultivar (Abouziena et al., 2008).

\subsubsection{Weed dry weight $\left(\mathrm{g} / \mathrm{m}^{2}\right)$ and weed control efficiency (WCE\%)}

Dry weight $\left(\mathrm{g} / \mathrm{m}^{2}\right)$ of grassy, broad-leaved, and total annual weeds was significantly affected by different weed control treatments as listed in Table (7). The results showed that the treatments could be ordered regrinding to the reduction on dry weight of grassy, broad-leaved and total annual weeds in both seasons in descending order as follow: the sequence of Onostar and Traxos followed by Atlantis, Broadway star, Pallas and hand weeding gave the highest reduction on dry weight of grassy, broad-leaved and total annual weeds in both seasons. The reduction percentages in dry weight of weeds as affected by the application of Atlantis, the sequence of Onostar and Traxos, Broadway star, Pallas and hand weeding twice were $97.5,97.7,96.2,96.5$ and $92.2 \%$ in the first season and 98.2, 97.7, 97.9, 96.5 and $95.7 \%$ in the second season, respectively, as compared with the untreated plots. The reduction in dry weight of weeds by the application of herbicides are considered a successful weed control technology as reported by Bari et al. (2020).

The highest efficacy of Atlantis herbicide may be due to this herbicide is a ready formulated and contained two sulfonylurea 
Table (6): Competitive ability of cultivars (CAC\%).

\begin{tabular}{|l|c|c|c|c|c|c|}
\hline \multirow{2}{*}{ Cultivars } & \multicolumn{3}{|c|}{$2017 / 2018$} & \multicolumn{2}{c|}{ 2018/2019 } \\
\cline { 2 - 7 } & $\begin{array}{c}\text { Grain yield } \\
\text { (ardab /fad) } \\
\text { of unweeded } \\
\text { (check) }\end{array}$ & $\begin{array}{c}\text { Grain yield } \\
\text { (ardab /fad) } \\
\text { of hand } \\
\text { weeding }\end{array}$ & CAC\% & $\begin{array}{c}\text { Grain yield } \\
\text { (ardab /fad) of } \\
\text { unweeded } \\
\text { (check) }\end{array}$ & $\begin{array}{c}\text { Grain yield } \\
\text { (ardab /fad) of } \\
\text { hand } \\
\text { weeding }\end{array}$ & CAC\% \\
\hline Misr-1 & 9.19 & 19.41 & 47.35 & 9.28 & 22.95 & 40.44 \\
\hline Misr-2 & 11.51 & 19.83 & 58.04 & 10.48 & 23.44 & 44.71 \\
\hline Shandaweel-1 & 10.36 & 22.65 & 45.74 & 12.01 & 24.70 & 48.62 \\
\hline Sids14 & 9.62 & 20.28 & 47.44 & 11.38 & 24.30 & 46.83 \\
\hline Giza-171 & 11.01 & 21.21 & 51.91 & 13.02 & 26.40 & 49.32 \\
\hline
\end{tabular}

Table (7): Effect of weed control treatment on dry weight of grassy, broad-leaved and total annual weeds $\left(\mathrm{g} / \mathrm{m}^{2}\right)$ and WCE\% in 2017/2018 and 2018/2019season .

\begin{tabular}{|l|c|c|c|c|c|c|c|c|c|c|c|c|}
\hline \multirow{4}{*}{$\begin{array}{l}\text { Weed control } \\
\text { treatment }\end{array}$} & \multicolumn{4}{|c|}{ Grassy weeds } & \multicolumn{3}{c|}{ Broad-leaved weeds } & \multicolumn{3}{c|}{ Total annual weeds } \\
\cline { 2 - 13 } & $\mathbf{2 0 1 7 / 2 0 1 8}$ & $\mathbf{2 0 1 8 / 2 0 1 9}$ & $\mathbf{2 0 1 7 / 2 0 1 8}$ & $\mathbf{2 0 1 8 / 2 0 1 9}$ & $\mathbf{2 0 1 7 / 2 0 1 8}$ & $\mathbf{2 0 1 8 / 2 0 1 9}$ \\
\cline { 2 - 13 } & $\begin{array}{c}\text { Dry } \\
\text { weight } \\
\text { (g) }\end{array}$ & $\begin{array}{c}\text { WCE } \\
\text { \% }\end{array}$ & $\begin{array}{c}\text { Dry } \\
\text { weight } \\
\text { (g) }\end{array}$ & $\begin{array}{c}\text { WCE } \\
\text { \% }\end{array}$ & $\begin{array}{c}\text { Dry } \\
\text { weight } \\
\text { (g) }\end{array}$ & $\begin{array}{c}\text { WCE } \\
\text { \% }\end{array}$ & $\begin{array}{c}\text { Dry } \\
\text { weight } \\
\text { (g) }\end{array}$ & $\begin{array}{c}\text { WCE } \\
\text { \% }\end{array}$ & $\begin{array}{c}\text { Dry } \\
\text { weight } \\
\text { (g) }\end{array}$ & $\begin{array}{c}\text { WCE } \\
\text { \% }\end{array}$ & $\begin{array}{c}\text { Dry } \\
\text { weight } \\
\text { (g) }\end{array}$ & $\begin{array}{c}\text { WCE } \\
\text { \% }\end{array}$ \\
\hline Pallas & 78.64 & $\mathbf{9 4 . 9}$ & 65.07 & $\mathbf{9 5 . 0}$ & 25.83 & $\mathbf{9 7 . 9}$ & 27.8 & $\mathbf{9 7 . 9}$ & 104.47 & $\mathbf{9 6 . 3}$ & 92.87 & $\mathbf{9 6 . 5}$ \\
\hline Atlantis & 42.53 & $\mathbf{9 7 . 3}$ & 31.8 & $\mathbf{9 7 . 5}$ & 28.01 & $\mathbf{9 7 . 7}$ & 15.53 & $\mathbf{9 8 . 9}$ & 70.55 & $\mathbf{9 7 . 5}$ & 47.33 & $\mathbf{9 8 . 2}$ \\
\hline Broadway-star & 69.32 & $\mathbf{9 5 . 5}$ & 39.13 & $\mathbf{9 7 . 0}$ & 35.4 & $\mathbf{9 7 . 2}$ & 17.2 & $\mathbf{9 8 . 7}$ & 104.72 & $\mathbf{9 6 . 2}$ & 56.33 & $\mathbf{9 7 . 9}$ \\
\hline Liprator fort & 1079.9 & $\mathbf{3 0 . 3}$ & 698.3 & $\mathbf{4 5 . 9}$ & 47.0 & $\mathbf{9 6 . 2}$ & 27.6 & $\mathbf{9 8 . 0}$ & 1126.9 & $\mathbf{5 9 . 6}$ & 725.9 & $\mathbf{7 2 . 6}$ \\
\hline Onostar followed by Traxsos & 39.65 & $\mathbf{9 7 . 4}$ & 24.2 & $\mathbf{9 8 . 1}$ & 23.27 & $\mathbf{9 8 . 1}$ & 37.8 & $\mathbf{9 7 . 2}$ & 62.92 & $\mathbf{9 7 . 7}$ & 62.0 & $\mathbf{9 7 . 7}$ \\
\hline Hand weeding Twice & 192.1 & $\mathbf{8 7 . 6}$ & 74.6 & $\mathbf{9 4 . 2}$ & 24.69 & $\mathbf{9 8 . 0}$ & 39.27 & $\mathbf{9 7 . 1}$ & 216.8 & $\mathbf{9 2 . 2}$ & 113.9 & $\mathbf{9 5 . 7}$ \\
\hline Untreated & 1549.1 & $\mathbf{0 . 0}$ & 1291.9 & $\mathbf{0 . 0}$ & 1243.1 & $\mathbf{0 . 0}$ & 1354.3 & $\mathbf{0 . 0}$ & 2792.2 & $\mathbf{0 . 0}$ & 2646.2 & $\mathbf{0 . 0}$ \\
\hline LSD 5\% & $\mathbf{4 8 . 1 4}$ & - & $\mathbf{3 0 . 6 1}$ & - & $\mathbf{4 1 . 0 1}$ & - & $\mathbf{2 8 . 7 6}$ & - & $\mathbf{5 1 . 1 6}$ & - & $\mathbf{4 0 . 7 9}$ & - \\
\hline
\end{tabular}

WCE\% = Weed control efficiency

active ingredients (mesosulfuron-methyl + iodosulfuron-methyl sodium). This herbicide inhibits the enzyme acetohydroxy acid synthase (AHAS). It acts via foliage and soil, effectively inhibiting the development of weeds new leaves. In addition, the target site of pyroxsulam inhibits acetolactate synthase (ALS), the key plant enzyme for the branched chain amino acids leucine, isoleucine and valine synthase. Mode of action of Onostar and Traxos. These results are in line with those obtained by Zand et al. (2010), Soltani and Saeedipour (2015) and Vasudev et al. (2017).

\subsubsection{Wheat yield and its component}

The results in Table (8) show significant impacts of weed control treatments on increasing wheat yield and its components in both seasons. The best treatments for increasing wheat yield and its components (no. of spikes $/ \mathrm{m}^{2}$, no. of kernels/spike, 1000 kernels weight, grain yield and harvest index) was achieved by herbicides (Pallas, Atlants, Onostar followed by Traxsos and Broadway-star) as well as hand weeding twice. The highest reduction in wheat yield and its component was recorded in unweeding (untreated).

All weed control treatments increased significantly no. of spikes $/ \mathrm{m}^{2}$. Pallas, Atlantis, Broadway-star, Onostar followed by Traxos and hand weeding twice gave the highest increment percentage in both seasons without any significant differences between these treatments. these treatments increased no, of spikes $/ \mathrm{m}^{2}$ by 93.8, 93.7, 90.1, 93.5 and 88.3, respectively, in the first season and by 86.4, 85.7, 79.72, 88.64 and 85.94 respectively, in the second seasons as compared to untreated.

Results revealed that Onostar followed by Traxos, Pallas, Atlantis, hand weeding twice and Broadway star increased no. of kernels/ spike by $32.9,30.1,29.9,28.7$ and $25.9 \%$ in the first season and by 34.2, 301, 29.5, 27.6 and $25.9 \%$ in the second season, respectively, compared with unweeded check. Whereas, these treatments increased 1000-kernal weight by $12.6,12.5,10.0,12.6$ and $11.2 \%$ in the first season and by 12.6, 12.5, 11.2, 12.6 and11.2\% in the second season, respectively, compared 
Table (8): Effect of weed control treatments on wheat yield and its components in 2017/2018 and 2018/2019 seasons.

\begin{tabular}{|c|c|c|c|c|c|}
\hline Weed control treatments & $\begin{array}{c}\text { No. } \\
\text { Spikes } \\
/ \mathbf{m}^{2} \\
\end{array}$ & $\begin{array}{c}\text { No. } \\
\text { kernels } \\
\text { / spike }\end{array}$ & $\begin{array}{c}\text { 1000- } \\
\text { kernel } \\
\text { weight }(\mathrm{g})\end{array}$ & $\begin{array}{c}\text { Grain } \\
\text { yield } \\
\text { (ardab/fad) }\end{array}$ & $\begin{array}{l}\text { Harvest } \\
\text { index } \%\end{array}$ \\
\hline \multicolumn{6}{|c|}{$2017 / 2018$} \\
\hline Pallas & 395.3 & 64.8 & 46.54 & 21.04 & 42.91 \\
\hline Atlantis & 395.2 & 64.7 & 45.49 & 20.58 & 46.65 \\
\hline Broadway-star & 387.8 & 62.6 & 46.00 & 19.40 & 43.89 \\
\hline Liprator fort & 264.5 & 55.1 & 43.24 & 14.37 & 38.37 \\
\hline Onostar followed by Traxsos & 394.7 & 66.2 & 46.44 & 20.89 & 44.11 \\
\hline Hand weeding Twice & 384.2 & 64.0 & 46.65 & 20.68 & 45.71 \\
\hline Untreated & 204.0 & 49.9 & 41.37 & 10.34 & 32.99 \\
\hline LSD 5\% & 11.89 & 3.2 & 1.04 & 0.67 & 2.46 \\
\hline \multicolumn{6}{|c|}{$2018 / 2019$} \\
\hline Pallas & 428.5 & 69.2 & 53.37 & 24.56 & 45.82 \\
\hline Atlantis & 426.8 & 69.0 & 52.51 & 23.96 & 44.78 \\
\hline Broadway-star & 413.0 & 67.1 & 52.91 & 22.88 & 42.82 \\
\hline Liprator fort & 294.9 & 58.5 & 49.38 & 16.73 & 41.86 \\
\hline Onostar followed by Traxsos & 433.6 & 71.4 & 53.08 & 24.31 & 49.42 \\
\hline Hand weeding Twice & 427.3 & 67.9 & 53.48 & 23.76 & 51.29 \\
\hline Untreated & 229.8 & 53.3 & 47.57 & 11.31 & 38.47 \\
\hline LSD 5\% & 8.80 & 3.3 & 1.38 & 0.71 & 3.35 \\
\hline
\end{tabular}

with unweeded check. Concerning the grain yield, all weed control treatments enhanced wheat grain yield in both seasons. Pallas, Onostar followed by Traxos, hand weeding twice and Atlantis increased wheat grain yield by $103.5,102.0,100.0$, and $99.0 \%$ in the first season and by $117.2,114.9,110.1$ and $111.8 \%$ in the second season, respectively, compared with unweeded check.

The results showed the beneficial effect of herbicides when added alone or in combination for weed control and enhancement of wheat yield and its component. These results are in harmony with those reported by Atnafu (2019). Also, the increases in wheat grain yield and its components by weed control treatments may be due to the role of these treatments in reducing wheat-weed competition by reducing weed density and dry matter with higher weed control efficiency which results in lesser removal of nutrients by weeds and ultimately crop might be benefited the productivity of wheat crop. The results are in line with those obtained by Deboer et al. (2006), Dawit et al. (2014) and Vasudev et al. (2017).

\subsection{Effect of interaction between wheat cultivars and weed control treatments on} 3.5.1. Weed dry weight $\left(\mathrm{g} / \mathrm{m}^{2}\right)$

Data in Table (9) clearly showed that the interaction between wheat cultivars and weed control treatments significantly affected the dry weight of grassy weeds, broad-leaved weeds and total annual weeds in both seasons. The interaction between cv. Misr-2 $\times$ Atlantis in the first season and cv. Misr-2 $\times$ Broadway-star in the second season gave the lowest values of dry weight of total annual weeds ( 35.3 and $23.3 \mathrm{~g}$ ) in the first and second season, respectively. whereas the highest values of total annual weeds was recorded in untreated with Shandaweel-1 cv. $\left(2990 \mathrm{~g} / \mathrm{m}^{2}\right)$ in the first season and Sids 14 $\left(2762 \mathrm{~g} / \mathrm{m}^{2}\right)$ and second seasons respectively. These results are in line with those reported by Bari et al. (2020).

\subsubsection{Wheat yield and its components}

Data in Table (10) shows the effect of interaction between weed control treatments and wheat cultivars on wheat yield and its components. Data revealed that the interaction effect between weed control treatments and wheat cultivars significantly affected on no. of spikes $/ \mathrm{m}^{2}$. Among the different treatments, the maximum no. of spikes $/ \mathrm{m}^{2}$ (416.8 and 455.3) was recorded with treatment of (Onostar followed by Tarxsos) with cv. Sids-14 in both seasons. The lowest no. of spikes $/ \mathrm{m}^{2}$ was recorded with unweeded treatments with all tested wheat cultivars. Alivi et al. (2004) and Bari et al. (2020) reported that the increase in number of tillers might be due to better weed control and the eradication of weeds eliminated the competition for moisture, light and nutrients and utilization of available source to the crop. 
Table (9): Dry weight $\left(\mathrm{g} / \mathrm{m}^{2}\right)$ of grassy, broad-leaved and total annual weeds as affected by interaction between bread wheat cultivars and weed control treatments in 2017/2018 and 2018/2019 seasons.

\begin{tabular}{|c|c|c|c|c|c|c|c|}
\hline \multirow[t]{2}{*}{ Cultivar } & \multirow[t]{2}{*}{ Weed control treatment } & \multicolumn{2}{|c|}{$\begin{array}{c}\text { Grassy weeds } \\
\left(\mathrm{g} / \mathrm{m}^{2}\right)\end{array}$} & \multicolumn{2}{|c|}{$\begin{array}{c}\text { Broad-leaved weeds } \\
\left(\mathrm{g} / \mathrm{m}^{2}\right)\end{array}$} & \multicolumn{2}{|c|}{$\begin{array}{l}\text { Total annual } \\
\text { weeds }\left(\mathrm{g} / \mathrm{m}^{2}\right)\end{array}$} \\
\hline & & $2017 / 18$ & 2018/19 & $2017 / 18$ & 2018/19 & $2017 / 18$ & 2018/19 \\
\hline \multirow{7}{*}{ Misr-1 } & Pallas & 46.8 & 56.0 & 6.0 & 34.8 & 52.8 & 90.8 \\
\hline & Atlantis & 26.0 & 17.8 & 20.8 & 21.3 & 46.8 & 39.0 \\
\hline & Broadway-star & 26.8 & 55.0 & 44.0 & 28.0 & 70.8 & 83.0 \\
\hline & Liprator fort & 961.3 & 770.8 & 26.8 & 7.3 & 988.0 & 778.0 \\
\hline & Onostar followed by Traxsos & 45.3 & 11.8 & 39.8 & 37.3 & 85.0 & 49.0 \\
\hline & Hand weeding Twice & 186.8 & 67.8 & 26.0 & 44.8 & 213.0 & 112.3 \\
\hline & Untreated & 1726.0 & 1330.3 & 1179.3 & 1319.3 & 2905.3 & 2649.8 \\
\hline \multirow{7}{*}{ Misr-2 } & Pallas & 107.8 & 62.3 & 14.0 & 17.3 & 121.8 & 79.8 \\
\hline & Atlantis & 32.0 & 26.3 & 3.3 & 16.3 & 35.3 & 42.8 \\
\hline & Broadway-star & 38.8 & 8.8 & 8.0 & 14.8 & 46.8 & 23.3 \\
\hline & Liprator fort & 1118.3 & 702.8 & 35.3 & 40.0 & 1153.8 & 742.8 \\
\hline & Onostar followed by Traxsos & 27.3 & 35.8 & 15.8 & 48.3 & 43.0 & 84.0 \\
\hline & Hand weeding Twice & 148.8 & 56.8 & 34.3 & 32.8 & 183.0 & 89.3 \\
\hline & Untreated & 1468.8 & 1191.0 & 1037.0 & 1315.3 & 2505.8 & 2506.3 \\
\hline \multirow{7}{*}{ Shandweel1 } & Pallas & 102.0 & 85.8 & 48.8 & 8.3 & 150.8 & 94.0 \\
\hline & Atlantis & 39.0 & 44.0 & 43.3 & 6.0 & 82.3 & 50.0 \\
\hline & Broadway-star & 128.5 & 62.0 & 43.0 & 6.3 & 171.5 & 68.3 \\
\hline & Liprator fort & 1049.8 & 772.8 & 39.8 & 28.8 & 1089.3 & 801.3 \\
\hline & Onostar followed by Traxsos & 89.3 & 22.0 & 16.3 & 40.3 & 105.8 & 62.3 \\
\hline & Hand weeding Twice & 284.3 & 49.3 & 18.0 & 30.0 & 302.3 & 79.3 \\
\hline & Untreated & 1559.3 & 1456.8 & 1430.8 & 1253.3 & 2990.0 & 2710.0 \\
\hline \multirow{7}{*}{ Sids14 } & Pallas & 106.8 & 59.3 & 22.0 & 49.0 & 128.8 & 108.3 \\
\hline & Atlantis & 67.0 & 29.8 & 39.3 & 9.8 & 106.3 & 39.3 \\
\hline & Broadway-star & 68.0 & 22.0 & 46.3 & 23.8 & 114.3 & 45.8 \\
\hline & Liprator fort & 952.8 & 610.3 & 71.0 & 32.8 & 1023.8 & 643.0 \\
\hline & Onostar followed by Traxsos & 18.3 & 10.3 & 25.8 & 35.3 & 44.0 & 45.8 \\
\hline & Hand weeding Twice & 162.3 & 40.3 & 37.3 & 39.0 & 199.5 & 79.3 \\
\hline & Untreated & 1401.5 & 1239.8 & 1333.3 & 1522.8 & 2735.0 & 2762.3 \\
\hline \multirow{7}{*}{ Giza-171 } & Pallas & 30.0 & 62.0 & 38.3 & 29.8 & 68.3 & 91.8 \\
\hline & Atlantis & 49.0 & 41.3 & 33.3 & 24.3 & 82.3 & 65.8 \\
\hline & Broadway-star & 85.0 & 48.0 & 35.8 & 13.3 & 120.8 & 61.3 \\
\hline & Liprator fort & 1317.3 & 635.3 & 62.3 & 29.3 & 1379.8 & 664.8 \\
\hline & Onostar followed by Traxsos & 18.0 & 41.3 & 18.8 & 27.8 & 36.8 & 69.0 \\
\hline & Hand weeding Twice & 178.3 & 159.0 & 8.3 & 50.0 & 186.5 & 209.0 \\
\hline & Untreated & 1590.3 & 1242.0 & 1235.3 & 1360.8 & 2825.8 & 2602.8 \\
\hline & LSD 5\% & 107.6 & 68.44 & 91.71 & 64.32 & 114.4 & 91.22 \\
\hline
\end{tabular}

Regardabing to the effect of interaction between weed control treatments and wheat cultivars on no. of kernels/spike, it was significant in the first season only. Maximum no. of kernels/spike was recorded with the herbicide treatment (Onostar followed by Traxsos) $\times$ Shandaweel-1 (77.0). The unweeded treatment (untreated) with all tested cultivars showed the lowest values no. of kernels/spike. These results were in harmony with Baldha $e t$ al. (1998). Data in Table (10) also showed that the interaction effect of bread wheat cultivars and weed control treatments had a significant effect on 1000-kernel weight (g) in the first season only. The highest 1000-kernel weight was measured in herbicide treatment of
Broadway star and hand weeing treatments (51.2 and $50.98 \mathrm{~g}$ ) with Shandaweel 1 cultivar. The maximum 1000 kernels weight might be due to severe competition and strong interaction of weeds that caused reduction in the photosynthetic activity that have caused reduction in weed free crop resulted in high 1000-kernels weight Ahmad et al. (2001).

The data given in Table (10) showed that the interaction between wheat cultivars and weed control treatments had a significant effect on grain yield (ardab/fad) in both seasons. The maximum grain yield was obtained from the interaction effect of cv. Shandweell $\times$ hand weeding in the first season (22.65 ardab/fad) and Shandweel $1 \times$ Pallas in the second season $(25.20$ 
Table (10): Wheat grain yield and its components as affected by interaction between bread wheat cultivars and weed control treatments in 2017/2018 and 2018/2019 seasons.

\begin{tabular}{|c|c|c|c|c|c|c|c|c|}
\hline \multirow[t]{2}{*}{ Cultivars } & \multirow[t]{2}{*}{$\begin{array}{l}\text { Weed control } \\
\text { treatments }\end{array}$} & \multicolumn{2}{|c|}{ No. of spikes $/ \mathrm{m}^{2}$} & \multirow{2}{*}{$\begin{array}{c}\begin{array}{c}\text { No. of } \\
\text { kernels/ } \\
\text { spike }\end{array} \\
2017 / 18\end{array}$} & \multicolumn{2}{|c|}{$\begin{array}{l}\text { Grain yield } \\
\text { (ardab/fad) }\end{array}$} & \multirow{2}{*}{$\begin{array}{c}\begin{array}{c}\text { 1000- } \\
\text { kernel } \\
\text { weight }(\mathrm{g})\end{array} \\
2017 / 18\end{array}$} & \multirow{2}{*}{$\begin{array}{c}\begin{array}{c}\text { Harvest } \\
\text { index } \\
(\%)\end{array} \\
2017 / 18\end{array}$} \\
\hline & & $2017 / 18$ & $2018 / 19$ & & $2017 / 18$ & $2018 / 19$ & & \\
\hline \multirow[t]{7}{*}{ Misr-1 } & Pallas & 393.3 & 417.0 & 56.3 & 20.51 & 24.24 & 40.43 & 40.43 \\
\hline & Atlantis & 386.8 & 429.3 & 52.8 & 20.90 & 24.70 & 45.23 & 45.23 \\
\hline & Broadway-star & 389.0 & 402.3 & 54.0 & 19.73 & 23.31 & 43.90 & 43.90 \\
\hline & Liprator fort & 276.8 & 307.0 & 47.8 & 12.83 & 16.16 & 35.98 & 35.98 \\
\hline & Onostar f.b Traxsos & 370.0 & 410.8 & 55.5 & 20.46 & 24.18 & 42.60 & 42.60 \\
\hline & Hand weeding Twice & 372.8 & 413.8 & 57.3 & 19.41 & 22.95 & 41.25 & 41.25 \\
\hline & Untreated & 200.0 & 222.0 & 46.8 & 9.19 & 9.28 & 28.80 & 28.80 \\
\hline \multirow[t]{7}{*}{ Misr-2 } & Pallas & 383.3 & 425.8 & 61.0 & 21.40 & 24.62 & 44.50 & 44.50 \\
\hline & Atlantis & 380.0 & 406.3 & 64.3 & 19.93 & 23.56 & 46.78 & 46.78 \\
\hline & Broadway-star & 363.3 & 392.3 & 62.0 & 19.00 & 22.47 & 42.23 & 42.23 \\
\hline & Liprator fort & 249.3 & 277.0 & 53.5 & 13.03 & 14.89 & 32.18 & 32.18 \\
\hline & Onostar f.b Traxsos & 390.0 & 417.8 & 61.0 & 19.84 & 23.45 & 43.08 & 43.08 \\
\hline & Hand weeding Twice & 383.3 & 425.3 & 67.3 & 19.83 & 23.44 & 43.48 & 43.48 \\
\hline & Untreated & 176.8 & 211.3 & 44.0 & 11.51 & 10.84 & 31.83 & 31.83 \\
\hline \multirow{7}{*}{$\begin{array}{l}\text { Shandwe } \\
\text { el1 }\end{array}$} & Pallas & 410.0 & 417.8 & 73.3 & 22.08 & 25.20 & 42.63 & 42.63 \\
\hline & Atlantis & 409.3 & 420.3 & 74.8 & 22.05 & 24.88 & 47.58 & 47.58 \\
\hline & Broadway-star & 400.0 & 408.8 & 69.3 & 20.70 & 24.23 & 51.20 & 51.20 \\
\hline & Liprator fort & 273.3 & 308.8 & 63.5 & 15.13 & 17.88 & 44.28 & 44.28 \\
\hline & Onostar f.b Traxsos & 406.8 & 451.3 & 77.0 & 21.98 & 25.06 & 43.20 & 43.20 \\
\hline & Hand weeding Twice & 404.8 & 449.0 & 74.0 & 22.65 & 24.70 & 50.98 & 50.98 \\
\hline & Untreated & 223.3 & 233.3 & 58.8 & 10.36 & 12.01 & 34.80 & 34.80 \\
\hline \multirow[t]{7}{*}{ Sids14 } & Pallas & 393.3 & 436.8 & 67.8 & 21.28 & 25.15 & 43.90 & 43.90 \\
\hline & Atlantis & 406.8 & 441.3 & 66.8 & 19.49 & 23.04 & 46.18 & 46.18 \\
\hline & Broadway-star & 400.0 & 431.0 & 64.3 & 17.85 & 21.10 & 39.10 & 39.10 \\
\hline & Liprator fort & 260.0 & 289.0 & 57.0 & 15.46 & 17.49 & 39.70 & 39.70 \\
\hline & Onostar f.b Traxsos & 416.8 & 455.3 & 71.8 & 20.94 & 24.75 & 44.98 & 44.98 \\
\hline & Hand weeding Twice & 393.3 & 436.8 & 61.3 & 20.28 & 24.30 & 47.10 & 47.10 \\
\hline & Untreated & 246.8 & 274.0 & 51.8 & 9.62 & 11.38 & 33.03 & 33.03 \\
\hline \multirow[t]{7}{*}{ Giza-171 } & Pallas & 396.8 & 445.0 & 65.8 & 19.94 & 23.57 & 43.10 & 43.10 \\
\hline & Atlantis & 393.3 & 436.8 & 65.0 & 20.54 & 23.61 & 47.50 & 47.50 \\
\hline & Broadway-star & 386.8 & 430.8 & 63.3 & 19.70 & 23.28 & 43.03 & 43.03 \\
\hline & Liprator fort & 263.3 & 292.8 & 53.8 & 15.40 & 17.21 & 39.73 & 39.73 \\
\hline & Onostar f.b Traxsos & 390.0 & 432.8 & 65.8 & 21.24 & 24.11 & 46.68 & 46.68 \\
\hline & Hand weeding Twice & 366.8 & 411.8 & 60.3 & 21.21 & 23.40 & 45.73 & 45.73 \\
\hline & Untreated & 173.3 & 208.3 & 48.0 & 11.01 & 13.02 & 36.48 & 36.48 \\
\hline LSD & & 26.8 & 19.7 & 7.1 & 1.51 & 1.58 & 5.49 & 5.49 \\
\hline
\end{tabular}

ardab/fad). The increment in grain yield might be due to eradication of weeds and find amount of $\mathrm{N}$ which aid to produce larger number of spikes $/ \mathrm{m}^{2}$ and number of kernels per spike. These results are in agreement with those of Shahid et al. (2005).

Data also indicated that the interaction effect between weed control practices and wheat cultivars on harvest index (\%) was significant in the first season only. The highest harvest index $(51.20 \%$ and $50.98 \%)$ was achieved with the treatment of Shandaweel-1× Broadway-star and Shandaweel-1 $\times$ hand weeding twice treatments, respectively. The results of increasing in $\mathrm{HI} \%$ with chemical and hand weeding treatment are in agreement with those reported by Tesfay et al. (2014).

\section{Conclusion}

From this study it could be concluded that to obtain the maximum grain yield of wheat cultivar Shandaweel-1 should be planted and weeds should be controlled by hand twice at 30 and 45days or by using herbicides Onostar followed by Traxsos, Atlantis, Pallas or Broadway. 


\section{REFERENCES}

Abdel-Majeed S.E.; Eissa S.T., Abd El-Hameed A.S., Mohamed M.M., Hamada A.A. et al., (2017). Sids 14 A new bread wheat cultivar. Egypt. J. Plant breed. 21(6):1059-1077.

Abouziena H.F, Faida A.A.S. and El-Desoki E.R. (2008). Efficacy of cultivar selectivity and weed control treatments on wheat yield and associated weeds in sandy soils. World J. Agric. Sci., 4 (3): 384-389.

Abusteit E.O., Mahrous N.M. and Saad F.F. (1991). Response of some wheat (Triticum aestivum L.) cultivars to chlorsulfuron foliar application. Egypt. J. Agro., 12(1-2) Special Issue: 97-102.

Ahmad S., Cheema Z.A., Iqbal R.M. and F.M. Kund (2001). Study of different herbicides for the control of broadleaved weeds in wheat. Sarhad J. Agric., 7:1-25.

Ahmad K., Shah Z., Khan I., Khan M. and Khan M.Q. (1993). Effect of post -emergence herbicides application and hand weeding on wheat and weed pressure. Pak. J. Weed Sci. Res., 6 (1-2): 40-45.

Alivi S.M., Chaudhry S.U. and Ali M.A. (2004). Evaluation of some herbicides for the control of weeds in wheat crop. Pak. J. Life Soc. Sci. 2: 24-27.

Atnafu D. (2019). Weed management methods on yield and yield components of bread wheat (Triticum aestivum L). Int. J. Res. and Innov. in Earth Sci., 6 (5): 63-78.

Baldha N.M., Patel J.C., Malavia D.D., and Kavani H.D. (1998). Efficacy of herbicides on weed control in irrigated wheat. Indian J. Weed Sci., 20(1): 89-90.

Bari A., Baloch M.S., Shah A.N., Khakwani A.A., Hussain I., Iqbal J., Ali A. and Bukhari M.A. (2020). Application of various herbicides on controlling large and narrow leaf weeds and their effects on physiological and agronomic traits of wheat. Planta Daninha, 38: Planta daninha. Viçosa 2020 Epub Feb. 10, 2020.

Bharat R., Kachroo D., Sharma R., Guptaand M. and Sharma A.K. (2012). Effect of different herbicides on weed growth and yield performance of wheat. Indian J. of Weed Sci., 44 (2): 106-109.

Brar L.S., and Singh B., (1997). Efficiency of diclofop-methyl against isoproturon resistant Phalaris minor relation to wheat cultivar and spacing. Brighton Crop Protection Conf.: Weeds Proc. of Inter. Conf., Brighton, UK, 17-20 Nov. (1): 331-336.

Bussan A.J., Burnside O.C., Orf J.H., Ristau E.A. and Puettmann K.J., (1997). Field evaluation of soybean (Glycine max) genotype for weed competitiveness. Weed Sci., 45: 31-37.

Dalley C.D, Bernardabs M.L. and Kells J.J. (2006). Effect of weed removal timing and spacing on soil moisture in corn (Zea mays). Weed Technol., 20:399-409.

Dawit D., Sharma J.J. and Tana T. (2014). Evaluation of herbicides and their combinations for weed management in bread wheat (Triticum aestivum L.) in Southern Ethiopia. Int. J. Nat. Novel Res. Life Sci., 1(1): 3147.

Deboer G.J., Thornburgh S. and Ehr R.J. (2006). Uptake, translocation and metabolism of the herbicide florasulam in wheat and broadleaf weeds. Pest Manage Sci., 62:316-24

Economic Affairs Sector, Ministry of Agricultural and land reclamation, Egypt (2020). Annual report.

Gomez K.A. and Gomez A.A. (1984). Statistical Procedures for Agricultural Research. $2^{\text {nd }}$ ed., John Wiley \&Sons, New York, USA.

Hamada A.A., Abo-Warda A.M., Abd ElMajeed S.A., El-Sayed E.A.M., Meshref M.K., et al. (2015). GIZA 171: A new high yielding bread wheat cultivar. Egypt J. Plant Breed. 19(7):2063- 2079.

Hamada A.A., Abd El-Majeed S.E., M. El-Saied E.A, Tawfeles M.B., El-Borhamy H.S.A., et al. (2017). MISR 1 and MISR 2: Two new, high yielding and rust resistant bread wheat cultivars. Menoufia J. Plant Prod., 2: $177-192$.

Hucl P. (1998). Response to weed control by four spring wheat genotypes differing in competitive ability. Can. J. Plant Sci., 78: 171-173.

Hussain S., Khaliq A., Matloob A., Fahad S. and Tanveer A. (2015). Interference and economic threshold level of little seed canary grass in wheat under different sowing times. Envir. Sci. Poll. Res., 22: 441-449.

Jabran K., Cheema Z.A., Farooq M., Basra S.M.A., Hussain M. and Rehman $\mathrm{H}$. (2008). Tank mixing of allelopathic crop water extracts with pendimethalin helps in 
the management of weeds in canola (Brassica napus) field. Int. J. of Agric. and Biol., 10 (3): 293-296.

Jagadish R. (2012). Developing terminal heat tolerant wheat. National Institute for Abiotic Stress Management (NIASM) Baramati, Pune, India.

Lopez-Granados F. (2011). Weed detection for site-specific weed management: mapping and real-time approaches. Weed Res., 51:1- 11 .

Mason H., Goonewardabene L. and Spaner D. (2008). Competitive traits and the stability of wheat cultivars in differing natural weed environments on the northern Canadian Prairies. J. Agric. Sci., 146: 2133.

Meena V., Kaushik M.K., Surendra K.M., Bhimwal J.P. and Chouhan B.S. (2017). Influence of pre and post emergence herbicide application on weed growth and nutrient removal in wheat (Triticum aestivum L.). J. Pharmacog. and Phytochem., 6 (6): 2413-24.

Mennan H. and Zandstra B. H. (2005). Effect of wheat (Triticum aestivum) cultivars and seeding rate on yield loss from Galium aparine (cleavers). Crop Prot., 24: 10611067.

Moustafa A. T. and El-Sawi S. (2014). Influence of sowing date on yield and its yield components for some Triticum durum cultivars having thermal responses in Middle Egypt. J. Agric. Sci. Mansoura Univ., 92(4): 1323-1338.

MSTAT-C (1989). MSTAT-C Statistical Program Version 2.10. Crop and Soil Sci. Dept., Michigan State University, USA.

Singh R., Singh A.P., Chaturvedi S., Rekha P.R., and Pal J. (2015). Metribuzin + clodinafop-propargyl effects on complex weed flora in wheat and its residual effect on succeeding crop. Indian J. Weed Sci., 47(4): 362-365.
Sadek Eman M., Tammam A.M., Tawfelies M.B., I.A. Amin, Hamada A., et al. (2013). SHANDAWEEL 1: A new bread wheat (Triticum aestivum L.) cultivar. J. Plant Production, Mansoura Univ., 4 (8): 1169-1183.

Soltani F. and Saeedipour S. (2015). Efficacy evaluation of some herbicides and different nitrogen levels for weed management and yield attributes in wheat. WALIA J., 31(S1): 39-43.

Täckholm V. (1974). Students' Flora of Egypt. Second edition, Published by Cairo University, Printed by Cooperative Printing Company, Beirut, pp: 887.

Tesfaye A., Sharma J. J. and Kassahun Z. (2014). Effect of weed control methods on weeds and wheat (Triticum aestivum L.) yield. World J. Agric. Res., 2: 124-128.

Vasudev M., Kaushik M.K., Surendra K., Meena J.P.B. and Chouhan B.S. (2017). Influence of pre and post emergence herbicide application on weed growth and nutrient removal in wheat (Triticum aestivum L.). J. Pharmacognosy and Phytochemistry, 6 (6): 2413-2418.

Verma S.K, Singh S.B., Meena R.N., Prasad S.K. and Meena R.S. (2015). A review of weed management in India: the need of new directions for sustainable agriculture. The Bioscan., 10: 253-263.

Zand E., Baghestani M.A., Alikhani M.A., Soufizadeh S., Khayami M.M., PourAzar R., Sabetie P., Jamali M., Bagherani N. and Forouzesh S. (2010). Chemical control of weeds in wheat (Triticum aestivum L.) in Iran. Crop Prot., 29: 12231231

Zeleke L., Abduselam F. and Berhanu H. (2019). Performance evaluation and adaptability study of durum wheat (Triticum turgidum var. durum) varieties in moisture stress areas of East Hararghe, Oromia. J. Agric. Res. Tech., 21(4): 190193. 


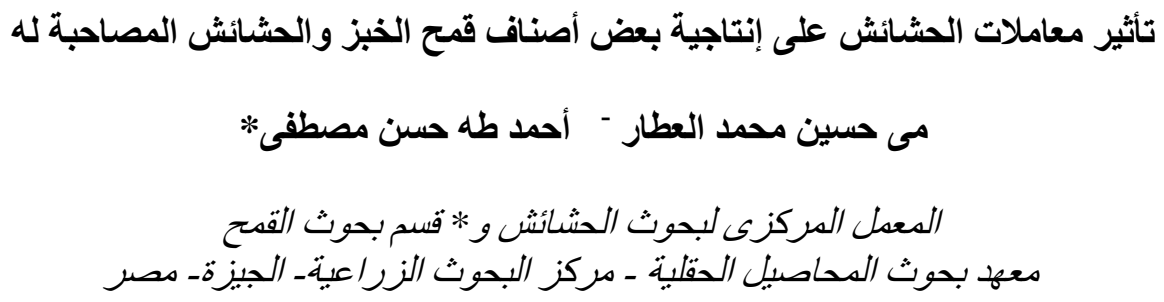

ملخص

أجريت تجربتين حقليتين خلال الموسمين الزراعيين 2018/2017 و2019/2018 بمحطة البحوث الزراعية

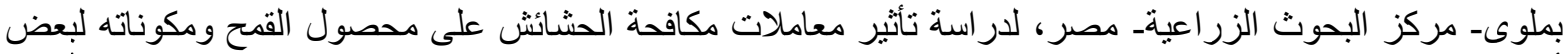

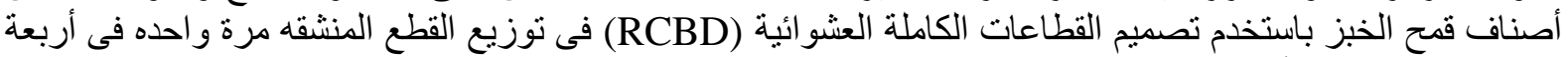

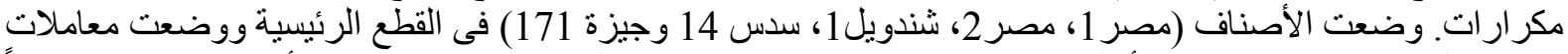

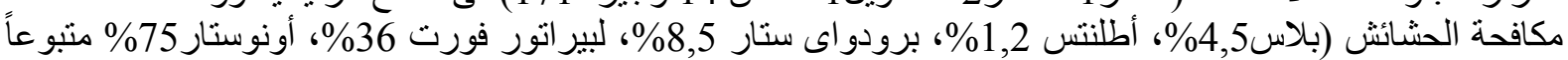

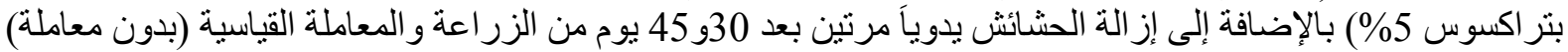

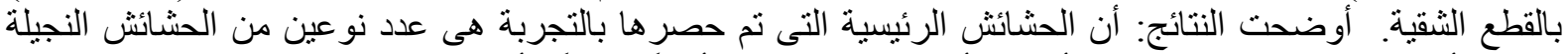

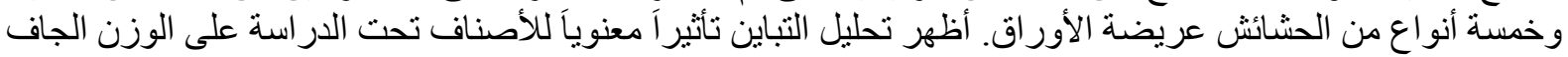

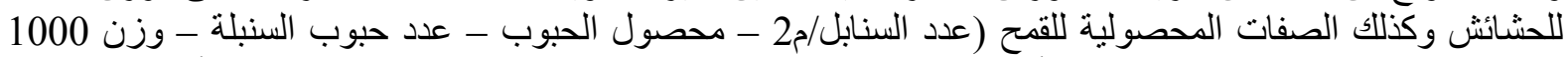

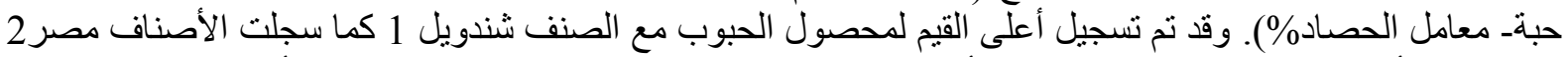

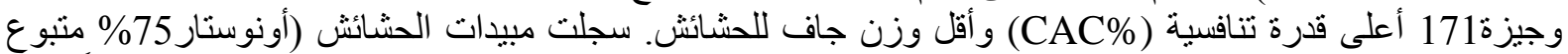

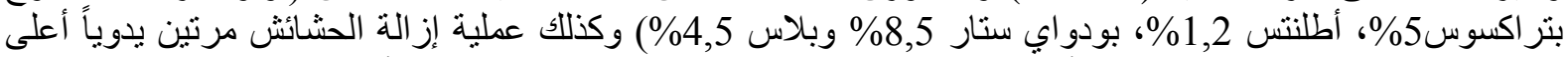

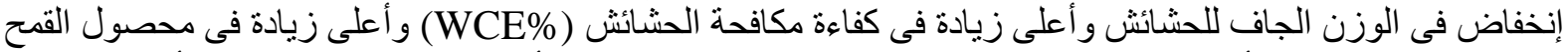

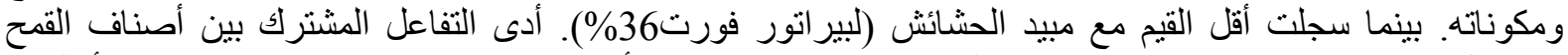

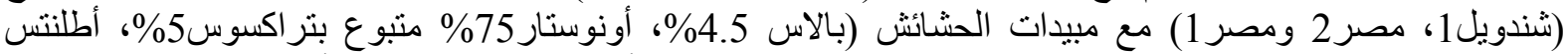

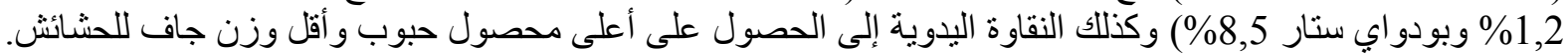

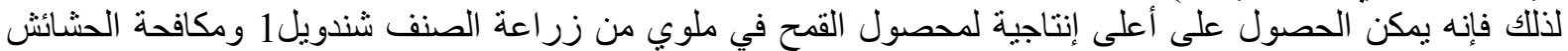

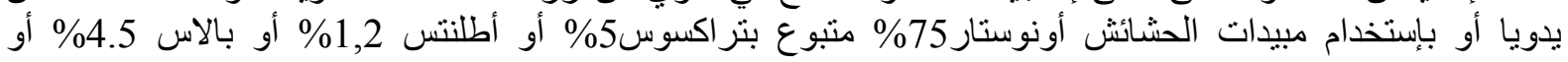

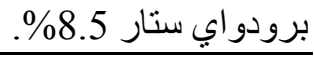

